\title{
Penanggulangan Permasalahan Kurikulum 2013 dalam Dunia Pendidikan Indonesia
}

\author{
Handi Wahyudi \\ Universitas Negeri Padang \\ Indonesia \\ Email : handiwahyudi12@gmail.com
}

\begin{abstract}
In the world of education in Indonesia, there are often problems that are fundamental to the education system. To improve the education system, changes need to be made to improve education in Indonesia, especially in the curriculum. At the time the world of Education in Indonesia had used the K-13 which focused on the character values of students at school and students were required to be able to combine the information they got from the teacher with the information that they had found themselves. This creates many problems in the implementation of the K-13. A small number of problems are the first, the school has not been able to implement this K-13, because it requires some time to prepare for the implementation of the K-13. Secondly, there are still teachers who do not understand the application of K-13 implementation, one of which is the use of learning media.
\end{abstract}

Keywords - problems, implementation, curriculum 2013

\section{PENDAHULUAN}

Perubahan kurikulum nasional pendidikan di suatu negara tidak dapat dipisahkan dari konteks yang melatar belakanginya. Kurikulum merupakan seperangkat rencana yang dirancang untuk mengatur mengenai tujuan, isi, dan bahan pembelajaran sebagai pedoman penyelenggaraan pembelajaran untuk mencapai tujuan Pendidikan nasional. Perubahan Kurikulum yang dibiasanya KTSP kini memakai Kurikulum 2013 dengan banyak polemic dan promblematika yang muncul.

Memakai Kurikulum 2013 merupakan suatu tantangan yang harus dihadapi baik itu tantangan internal maupun eksternalnya, baik tiu standar nasional Pendidikan maupun perkembangan zaman yang lebih maju. Walaupun KTSP di ganti dengan K13 perubahan ini sangat disikapi dengan bijaksana jangan sampai karena perubahan kurikulum ini tujuan yang telah ditetapkan sebelumnya tidak tercapai. Dengan menerapkan K13 di dunia Pendidikan saat ini, semua nya dituntut maksimal baik itu peserta didiknya maupun para gurunya, para guru harus memiliki empat kompetensi dan tidak boleh menguranginya karena sangat berpengaruh pada proses pembelajaran.

Dalam Implementasinya K 13 banyak ditemukan permasalahan yang terjadi. Salah satunya Sekolah yang belum mampu untuk melaksanakan K 13. Hal ini dikarenakan masih ada kendala-kendala sekolah seperti sarana prasarana sekolah yang kurang memadai dalam penerapannya. K 13 ini lebih menekankan pada penggunaan teknologi dan informasi dalam pelaksanaannya disekolah. Menurut (Ruja \& Sukamto, 2015)pada sekolah yang menerapkan K 13 pelaksanaannya lebih berbasis teknologi informsi. Teknologi sangat berpengaruh dalam meningkatkan kualitsa sekolah.

Hal inilah yang membuat sebagian besar sekolah banyak terkendala dalam kurikulum 2013. Karena teknologi ini perlu adanya sarana prasarana yang lengkap pada suatu sekolah. Selajutnya adanya problema guru yang kurang paham dalam penerapannya karena K 13 ini. Dan menurut (Sudarsana, 2018) mindset guru hanya untuk mengajar sedangkan pada kurikulum 2013 lebih menekankan harus mampu mengarahkan siswa lebih kreatif, aktif, produktif dan berfikir kritis. Karena mindset itu membuat guru kutrang paham tersebut.

\section{METODE PENELITIAN}

Atas dasar latar belakang sebagaimana disampaikan, maka penelitian ini akan difokuskan untuk mencari jawaban tentang penanggulangan permasalahan kurikulum 2013 dalam dunia Pendidikan Indonesia untuk meningatkan kualitas Pendidikan sesuai dengan tujuan Pendidikan nasional.

Jenis penelitian ini adalah deskriptif dengan pendekatan kualitatif. Tujuannya untuk mengungkap fakta yang terdapat di lapangan dan memusatkan pada pemecahan masalah yang ada pada masa sekarang.

\section{KAJIAN TEORI}

\section{A. Konsep Dasar Kurikulum}

Kurikulum merupakan perangkat mata pelajaran dan program pendidikan yang diberikan oleh suatu lembaga penyelenggara pendidikan yang berisi rancangan pelajaran yang akan diberikan kepada peserta didik dalam satu periode jenjang pendidikan. Penyusunan perangkat mata pelajaran ini disesuaikan dengan keadaan dan kemampuan setiap jenjang pendidikan dalam penyelenggaraan pendidikan tersebut serta kebutuhan lapangan kerja. Lama waktu dalam satu kurikulum biasanya disesuaikan dengan maksud dan tujuan dari sistem pendidikan yang dilaksanakan. Kurikulum ini dimaksudkan untuk dapat mengarahkan pendidikan menuju arah dan tujuan yang dimaksudkan dalam kegiatan pembelajaran secara menyeluruh.

Pada masa saat ini Pendidikan Indonesia telah menerapkan kurikulum 2013 ynag sebelumnya menggunkan Kurikulum KTSP. Kurikulum 2013 ini merupakan kebijakan baru pemerintah untuk meningkatkan kualitas Pendidikan Indonesia agar menjadi lebih baik. Menurut (Pardomuan M J N Pardomuan, 2013) digantikannnya kurikulum ini agar 
kemampuan peserta didik lebih kreatif, inovatif, serta berkarakter dan juga dalam kurikulum 2013 ini lebih menilai kepada aspek afektif, psikomotor dan keterampilan peserta didik.

\section{B. Permaslahan Kurikulum 2013 di Dunia Pendidikan}

Banyak sekali polemic dan problematika yang terjadi mengenai penerapan pelaksanaan kurikulum 2013 ini, tidak hanya pada peserta didiknya yang terkendala, tetapi guru dan sumber daya yang lain pun mengalami permasalahan.

Bebrapa permasalahan yang terjadi saat penerapam Kurikulum 2013 antara lain yaitu:

1. Guru mata pelajaran yang masih kurang paham akan konsep pelaksanaan kurikulum 2013 ini, karena para guru masih kebingungan dengan Teknik apa dia mengajar peserta didik. Menurut (Ruja \& Sukamto, 2015) sebagian guru masih kekurangan proses pelatiahan karena waktu pelatihan, kemampuan guru, dan tidak focus dalam pelatiahan persiapan $\mathrm{K} 13$.

2. Guru masih belum pandai secara utuh memadukan antara materi pelajaran dengan sumber pembelajaran serta dengan menggunakan media pembelajarannya.

3. Guru salah pengertian atau salah kaprah, karna beranggapan bahwa pada K13 ini guru tidak perlu menjelaskan padahal pada mata pelajaran tertentu guru tetap perlu menjelaskan.

4. Peserta didik yang belum terbiasa dengan metode pembelajaran karena yang biasanya pada KTSP mereka hanya menerima materi dari guru mata pelajaran dan pada Kurikulum 2013 ini mereka dituntut untuk lebih aktif, kreatif dalam pelaksanaan pembelajaran.

5. Tidak sebanding antara isi kurikulum 13 dengan media pembelajaran, dimana $\mathrm{k} 13$ ini ada pembelajaran berbasis teknologi sedangkan media pembelajaran yang berupa teknologi itu tidak ada.

\section{Penanggulangan Permasalahan Kurikulum 2013}

Setiap masalah tentu ada solusi atau penyelesaiannya, mengenai permasalahan penerapan pelaksanaan Kurikulum 2013 ini tentu ada solusinya yaitu dengan bekerja sama dan menyadari apa yang kurang.

Ada beberapa cara solusi mengatasi permasalahan yang terjadi akibat Kurikulum 2013, diantaranya yaitu:

1. Menurut (Alawiyah, 2015) Memberikan Pendidikan dan pelatihan kepada para guru terkhususnya guru mata pelajaran sehingga mereka dapat memahami dan mengerti apa yang akan mereka ajarkan.
2. Menyediakan media pembelajaran dan sumber sumber belajar sehingga antara isi kurikulum dengan materi pembelajaran dapat berkesinambungan karna adnya media dan sumber pembelajaran.

3. Memberikan motivasi kepada peserta didik bahwasanya dengan kurikulum 2013, peserta didik akan lebih kreatif dan semngat dalam pembelajaran.

4. Menyediakan media pembelajaran yang berbasis teknologi sesuai denga isi kurikulum sehingga tidak mengalami ketertinggalan.

Menurut (Sudarsana, 2018) penggunaan teknologi juga sangat berpengaruh terhadap perkembangan para peserta didik bagaiamana siswa harus menemukan sendiri dan mentransformasikan informasi kompleks, mengecek informasi baru dengan aturan-aturan lama dan merevisinya apabila aturan-aturan itu tidak lagi sesuai. Dari hal tersebut guru juga harus berperan mengatur Batasan - Batasan pembelajaran yang akan dipelajari.

(Sudarsana, 2018) memaparkan Optimalisasi penggunaan teknologi dalam implementasi kurikulum di sekolah terdiri dari tiga tahapan yaitu tahap perencanaan, pelaksanaan, dan analisa. Dari segi perencanaan,guru merumuskan permasalahan dan memotivasi siswa, yang disesuaikan dengan silabus danRencana Pelaksanaan Pembelajaran (RPP). Dari segi pelaksanaan, pada pelaksanaaneksplorasi guru melibatkan pebelajar mencari informasi yang luas dan dalam tentangpermasalahan yang akan dibahas dengan menggunakan teknologi, pada pelaksanaanelaborasi pembelajar membagi pebelajar dalam bentuk kelompok kecil yang bertujuan untukmengembangkan kemampuan pebelajar dalam bekerja sama dan berkomunikasi padapelaksanaan konfirmasi guru memberikan umpan balik dan memberikan penegasan terhadaphasil eksplorasi dan elaborasi.

\section{PENUTUP}

Kurikulum 2013 adalah kurikulum pengganti KTSP, yang menerapkan para peserta didik harus lebih kreatif, aktif, inovatif dalam menemukan informasi dan mengabungkan segala informasinya yang didapatkannya. Dari hal tersebut terjadi permasalahan pada pelaksanaan K 13 dikarenakan pergantian kurikulum. Hal ini perlu ditindak lanjuti untuk menanggulangi permasalahan tersebut sehingga tercapainya kualitas Pendidikan yang layak. Hal tersebut harus perlu persiapan mulai dari sarana prasarana yang akan mendukung kurikulum 2013 dan juga untuk para guru diberikan pemahaman terhadap proses pelaksanaan pembelajaran pada kurikulum 2013 ini. Sehingga terciptanya suasana belajar yang interaktif dan nyaman sesuai denga tujuan dari Kurikulum 2013. 


\section{DAFTAR PUSTAKA}

[1] Alawiyah, F. (2015). Kesiapan Guru dalam Implementasi Kurikulum 2013. Kajian Singkat, VI(15), 9-11.

[2] Pardomuan M J N Pardomuan. (2013). KURIKULUM 2013 DAN IMPLEMENTASINYA DALAM PEMBELAJARAN. E-Journal Universitas Negeri Medan, 6, 17-29.

[3] Ruja, I. N., \& Sukamto. (2015). Survey Permasalahan Implementasi Kurikulum Na- Sional 2013 Mata Pelajaran Ilmu Pengetahuan Sosial Sekolah Menengah Pertama Di Jawa Timur. Jurnal Sejarah Dan Budaya, xi(2), 193-199. Retrieved from http://journal.um.ac.id/index.php/sejarahdan-budaya/article/view/5001

[4] Sudarsana, I. K. (2018). Optimalisasi Penggunaan Teknologi Dalam Implementasi Kurikulum Di Sekolah (Persepektif Teori Konstruktivisme). Jurnal Ilmu Pendidikan, 1(1), 8-15. Retrieved from http://jayapanguspress.penerbit.org/index.php/cetta/article /view/41 